INFORMASI: Kajian Ilmu Komunikasi-ISSN (p) o126-065o; ISSN (e) 2502-3837

Vol. 48. No. 2 (2018). Pp.295-308. doi: http://dx.doi.org/10.21831/informasi.v48i2.15873

\title{
STATE POSITION AMONG OF THE INFORMATION TECHNOLOGY PARADIGM: \\ REVIEW OF THE MEDIA LITERACY MOVEMENT BY DIY KPID AND BTKP DIY
}

\author{
Firly Annisa \\ f.annisa@keele.ac.uk \\ Keele University, United Kingdom
}

\begin{abstract}
The Democratic System of Pancasila that has been chosen by Indonesian founders give several consequences. The state needs to be responsible for regulating equality policies for every citizen. Not only about the issue of equitable economic resources but also equal access to information. In the context of the country, democracy and markets equal access to information can be understood as information technology paradigm. This paradigm means that all systems that use by technology information are defined by networking sense, which is an empowering citizen to influence a wide variety of processes. Through the observation and depth of methods, this research examines the role of the Yogyakarta Provincial Education and Sports Agency for educating students and the equitable distribution of information technology. The city was chosen as a research umbrella carried out by Media Literacy Activists Network in 2017. As result of this research shows that literacy education efforts were carried out by Indonesia Broadcasting Commision of Yogyakarta Special Region were still struggling in a protectionist perspective, while The Institute of Government Education Communication Technology in Yogyakarta Province is using creative media approach as an effort to use technology as part of empowerment.
\end{abstract}

Keywords: Digital Literacy, Citizen, Democracy, Government.

\section{POSISI NEGARA DI TENGAH PARADIGMA TEKNOLOGI INFORMASI: TINJAUAN GERAKAN LITERASI MEDIA OLEH KPID DIY DAN BTKP DIY}

\begin{abstract}
Abstrak
Sistem Demokrasi Pancasila yang dipilih oleh para pendiri bangsa Indonesia melahirkan beberapa konsekuensi logis. Diantaranya menuntut peran negara dalam mengatur kebijakan pemerataan keadilan. Keadilan tidak hanya pada persoalan pemerataan sumber-sumber ekonomi, namun juga pemerataan akses informasi. Dalam masyarakat, akses informasi ini di sebut sebagai paradigma teknologi informasi. Paradigma ini berarti ketika semua sistem yang menggunakan teknologi informasi didefinisikan oleh 'logika jaringan' yang memungkinkan mereka memengaruhi suatu varietas luas prosesproses dan organisasi-organisasi. Ketika "logika jaringan" tersebut telah terjadi dengan melimpahnya akses informasi di dunia maya lalu langkah-langkah seperti apa yang diterapkan oleh Negara khususnya Dinas Pendidikan dan Olahraga Provinsi Yogyakarta
\end{abstract}


untukmendidiksiswa dan guru sebagai bagian daripemerataan keadilan dalam teknologi informasi? Kota ini dipilih berkaitan dengan payung riset yang dilakukan bersamasama dengan Jaringan Pegiat Literasi Media (Japelidi) pada tahun 2017. Penelitian ini menggunakan instrumen yang telah disusun melalui pengayaan teori digital literasi berkaitan dengan tujuan penelitian yaitu, memetakan aktivitas Literasi Digital. Melalui desk study, observasi dan wawancara mendalam sebagai metode, peneliti menemukan upaya pendidikan literasi yang dilakukan KPID DIY masih berkutat dalam perspektif proteksionis sedangkan BTKP DIY lebih pada pendekatan media kreatif sebagai upaya menggunakan teknologi sebagai bagian dari pemberdayaan.

Kata Kunci: Literasi Digital, Warganegara, Demokrasi, Pemerintah

\section{PENDAHULUAN}

Pada pertengahanabad ke-15 media cetak pertama kali di temukan di Eropa dengan didahului dengan penemuan mesin uap oleh Alexander Gutenberg, pada saat itu Injil adalah buku yang pertama kali diproduksi, persisnya pada tahun 1456. Komunikasi media tulis ini menjadi bekal saluran imperialisme, bangsa Barat yang menjajah bangsa Timur seperti Indonesia dan juga bangsa Barat mendidik masyarakatnya sendiri. Setelah berakhirnya perang dunia pertama tahun 1918, industri media cetak menjadi sentral dari berbagai persoalan politik, intelektual, dan kehidupan budaya di Amerika seperti di kota Boston, New York, dan Philadelphia. Kota-kota besar menjadikan kebudayaan baca menjadi basis kemajuan peradaban.

Puncaknya pada tahun 1861 Amerika mendapatkan predikat "highest literacy rate in the world". Pada waktu yang sama bangsa Indonesia adalah negara yang masih belum terbentuk. Kebudayan membaca belumlah ada, bahkan bangsa ini masih di bawah kekuasaan rezim kolonialisme sebagai bangsa yang terjajah. Sejak abad ke-16 dan seterusnya budaya kepulauan Nusantara masih "dipelihara” langsung oleh kebijakankebijakan kolonial. Bangsa Indonesia belumlah lahir bahkan belum menemukan konsep pendidikan. Pada tahun 1895 mulai ditemukannya film bergerak di Paris Perancis oleh Lumiere bersaudara, dan diperlukan lebih dari lima puluh tahun berikutnya lahir penemuan media televisi tepatnya pada 1948 di Amerika.

Perubahan bentuk media ini berangsur- angsur dan memerlukan waktu, baik dalam penemuannya maupun sampai di konsumsi masyarakat luas di negara Barat. Setelah periode ditemukannya media massa berbentuk one way communicaton atau satu arah, lahirlah media baru yang menggunakan logika two ways communication atau komunikasi dua arah bahkan berbagai arah. Komunikasi berbagai arah ini dimulai pada periode 9o-an ketika mulai ditemukannya teknologi siber. Hal ini dapat menjadi refleksi bersama bahwa dalam sejarah ditemukannya media akan berjalan linier dengan perkembangan peradaban masyarakat. Bangsa di dunia yang terlebih dahulu maju adalah bangsa yang dapat memproduksi media, mampu membaca, menulis dan pada akhirnya reflektif terhadap apa yang ia baca sehingga disebut literate.

Idealnya bangsa Indonesia melewati fase tulisan bermedia seperti di atas, yaitu membaca, menulis, dan memahami teksteks dari sumber-sumber yang terpercaya barulah beralih pada fase visual. Namun bukannya memahami dan menikmati medium sesuai periode dan kesiapan bangsa, Indonesia seperti negara-negara jajahan di bagian dunia lain justru sudah dibanjiri arus informasi melalui koneksi internet yang melimpah ruah salah satunya karena lahirnya globalisasi. Akibatnya telah dapat terlihat, masyarakat Indonesia gagap bermedia, mengenali dan justru menjadi bagian dari penyebaran pesan-pesan kebohongan. Hal ini merujuk pada kesimpulan penting, kemampuan literasi digital tidak datang dengan sendirinya. 


\section{KAJIAN PUSTAKA}

\section{Negara dalam Perspektif Teori Komunikasi}

Khalayak sebagai entitas pasif sudah menjadi paradigma kuat dalam ranah ilmu komunikasi. Dicetuskan oleh ahli politik Amerika Harold Laswell dikenal dengan model komunikasi linier yang menekankan rangkaian peristiwa komunikasi yang selalu satu arah "Who (says) What (to) in Which Channel to Whom, with What Effect" (McQuails, 1964: 40). Model Laswell saat itu berkaitan dengan awal penemuan media massa khususnya televisi di Amerika sekitar periode tahun 1948. Di mana media masih sangat terbatas dimiliki dan di akses oleh masyarakat dunia. Posisi media massa yang selalu diasumsikan lebih kuat daripada khalayak menjadi inti pemikiran model komunikasi ini. Dalam kaitannya menyampaikan pesan, media dianggap memiliki otoritas dalam menentukan sikap dan pemikiran khalayak setelah menerima sebuah pesan. Sebaliknya khalayak terlihat lebih patuh dan menerima apa yang disampaikan media. Linieritas pesan ini dikarenakan media yang masih terbatas dan masyarakat yang dianggap belum dapat berpikir kritis.

Retorika politik dan propaganda menjadi tujuan politik setelah perang dunia ke-dua saat itu. Pada situasi setelah perang besar berhasil dihentikan dan berakhirnya kolonialisme, negara-negara sedang bangkit dan bergegas dalam pembangunan. Masyarakat sipil menjadi bagian dari pembangunan negara, maka politik memerlukan obyek dan subyek untuk menerima pesan-pesan dari pemerintah. Pada masa itulah pesan-pesan propaganda diciptakan untuk menumbuhkan nasionalisme dan semangat membangun. Berakhirnya perang dunia kedua menjadikan Amerika sebagai salah satu negara pemenang. Maka ia harus menampilkan dirinya yang kuat, dalam membangun kepercayaan dunia. Citra-citra positif pemerintah disajikan melalui jurnalisme media yang memihak pilihan-pilihan politik negara terhadap rakyatnya.

Tidak terkecuali di negara-negara yang baru saja bebas dari penjajahan seperti Indonesia. Proses komunikasi Politik masih satu arah yang menginginkan warga negara untuk tunduk dan patuh terhadap keputusan-keputusan pemerintah dalam terma kebangkitan revolusi pada Orde Lama dan pembangunan Nasional saat Orde Baru. DalamkonteksmasakepemimpinanSoekarno pesan-pesan perjuangan didengungkan setelah kemerdekaan. Penolakan Soekarno terhadap musik-musik Koes Plus yang berbicara soal percintaan muda mudi, patah hati dan kebebasan disingkirkan sebagai upaya perubahan mental dan perilaku rakyat (Nugroho \& Herlina, 2013: 45). Sejalan dengan upaya "mendidik" rakyat untuk keluar dari Imperialisme Barat beserta budaya yang menyertainya. Selera kemudian menjadi persoalan penting untuk dikendalikan. Pada posisi inilah proteksi terhadap pesanpesan media dan budaya populer dilakukan oleh Soekarno karena rakyat dianggap akan mudah terpengaruh arus informasi daripada berusaha untuk melawannya.

Era berikutnya adalah masa setelah Soekarnodirebutlegitmasikekuasaannyaoleh seorang Letnal Kolonel bernama Soeharto. Dengan Supersemar (Surat Perintah Sebelas Maret) tampuk kekuasaan proklamator berpindah dengan cepat di tangan militer Soeharto. Angin politik yang berubah menimbulkan konsekuensi yang baru pula. Keakraban paham sosialis yang diusung saat paska kemerdekaan beralih menjadi musuh. Kran "Barat" dibuka kembali bersamaan dengan didirikannya TVRI sebagai televisi Nasional yang menjadi etalase globalisasi. Saat itu TVRI sempat menyediakan slot untuk iklan sebagai konsekuensi dibukanya UU Penanaman Modal Asing 1967. Masuknya modal asing menyediakan ceruk pasar iklan di media massa termasuk di TVRI. Meskipun belakangan dengan alasan menghindari budaya konsumtif maka iklan-iklan tersebut ditiadakan (Sen dan Hill, 2000: 15).

TVRI dan RRI sebagai televisi nasional digunakan sebagai corong pemerintah untuk menampilkan Soeharto sebagai 
Bapak Pembangunan yang tegas, dicintai rakyatnya dan berhasil membangun ekonomi. Pembangunan pada sektor fisik menjadi fokus dalam pemerintahan Orde Baru. Kembali menyoal dengan proses komunikasi, penggunakan terma Ekonomi dan Komunikasi Pembangunan sering dipraktikkan pada negara yang sedang berkembang seperti di Indonesia pada waktu itu. Hal ini selaras dengan situasi politik dan cara pandang penguasa yang belum membangun masyarakat jaringan dengan menempatkan warga negaranya sebagai agen komunikator atau user. Namun sebaliknya masih komunikan atau receiver dan dengan subyek pembangunan adalah pemerintah, rakyat sebagai obyeknya.

Teori Diffusion of Innovations (1964) yang di cetuskan Everett Rogers menjadi fondasi komunikasi pembangunan negaranegara yang sedang membangun sistem politik, sosial, budaya dan hukumnya. Diperlukan kekuatan komunikasi dari pemerintah atas nama pembangunan, yang menciptakan masyarakat tunduk patuh atas keseragaman. Pemerintah bersama media massa menjadi agen dominan menciptakan pesan-pesan politik, propaganda, bahkan dapat pula manipulatif. Teori difusi inovasi ini menggunakan logika khalayak pasif sebagai obyek politik pemerintahan untuk mencapai perubahan perilaku yang diinginkan penguasa. Everett mendefinisikan difusi sebagai proses sebuah inovasi dikomunikasikan melalui berbagai saluran dan jangka waktu tertentu dalam sebuah sistem sosial (Rogers, 1983: 40).

Runtuhnya Orde Baru pada masa 1998, tidak serta merta membuat pemerintah melihat rakyatnya berbeda. Respon yang terjadi saat masatransisi diera tersebutadalah kebijakan pembuatan berbagai Komisi yang mengatur segala persoalan yang fundamental terjadi pada masa sebelumnya. Sistem penyiaran adalah salah satunya. Titik tolak pemikiran yang digunakan ialah pengelolaan sistem penyiaran yang merupakan ranah publik harus dikelola oleh sebuah badan independen yang bebas dari campur tangan pemodal maupun kepentingan kekuasaan.
Undang-undang Penyiaran Nomor 32 Tahun 2002 merupakan dasar utama bagi pembentukan Komisi Penyiaran Indonesia (KPI). Meskipun memiliki semangat positif namun cara pandang pesan media yang memberikan pengaruh pada khalayak masih mendominasi berbagai kebijakan negara saat itu. Bahkan hingga hari ini, selang tujuh belas tahun kemudian. Sensor berupa blurring gambar pada bagian tertentu tubuh perempuan pada tayangan televisi merupakan salah satu contoh implementasi perspektif tersebut.

\section{Orientasi dan Kompleksitas Literasi}

Dalam terminologi literasi pada umumnya masyarakat memahami empat komponen di dalamnya, yaitu membaca dan menulis, berbicara dan mendengar. Namun menurut Hobbs (2010: 17) literasi sesungguhnya lebih dari itu. Literasi adalah kemampuan untuk mengartikulasikan gagasan, ide, memberi respon atas sebuah peristiwa dan bagian dari ekspresi dan komunikasi dalam kehidupan sehari-hari. Artinya konsep literasi adalah bagian dari kemampuan untuk membagikan makna melalui sistem simbol yang bertujuan untuk ikut berpartisipasi dalam kegiatan di masyarakat. Akibatnya apa? kemampuan literasi juga berkaitan dengan kemampuan untuk berinteraksi, menggunakan kata demi kata dan menjadikan sebuah kalimat yang bermakna dalam kehidupan sosial. Tidak itu saja, karena berkaitan dengan sistem bahasa, literasi berarti juga mampu menggunakan gambar, grafik desain, suara, musik dan interaksi dalam komunikasi sehari-hari.

Dilain pihak menurut Leu dkk, (2004: 1574) karena berbagai perkembangan pengetahuan, sosial dan budaya bentuk dan tipe teks mengalami banyak perubahan sejak lebih dari lima puluh tahun yang lalu. Dalam perubahan bentuk pesan, media dan sistem bahasa tersebut juga diperlukan berbagai bentuk kompetensi yang dibutuhkan agar individu dan komunitas dapat berkomunikasi dalam ruang-ruang yang memiliki etika, setara, memahami maksud satu sama lain 
untuk mencapai tujuan bersama. Interseksi berbagai ilmu ini perlu ditemukan dalam berbagai kajian dari lintas ilmu dan diwadahi oleh kebijakan negara.

Hal ini mengakibatkan dalam setiap lini kehidupan sosial, lahir diperlukan berbagai variasi literasi yang menjawab tantangan peradaban dari waktu kewaktu. Berbagai variasi tersebut diantaranya; literasi informasi, literasi media, pendidikan bermedia, literasi visual, literasi berita, literasi media kesehatan, dan literasi digital. Setiap terminologi dan area kajian memiliki keunikan dan kekhususan untuk menjawab tantangan peradaban masyarakat sejak pertengahan abad ke-2o. Terminologi ini juga merefleksikan perihal persoalan literasi adalah sesuatu yang kompleks, membutuhkan latar belakang berbagai disiplin ilmu, dengan cakupan pengetahuan yang luas dengan kolaborasi berbagai macam kemampuan pula.

Gerakan literasi media mengenal tiga orientasi yang dominan 1) protecsionist orientation: yang cenderung melindungi khalayak dengan logika pasif dan media sangat berkuasa. Logika ini cenderung dipraktekkan dalam ranah pendidikan dan institusi politik. 2) Promoting orientation: mendorong aktivitas yang menstimulasi kesadaran bagi khalayak media dalam upaya pemberdayaan. Hal ini berdasarkan pemikiran bahwa media baru menawarkan kesempatan bagi warganegara dan potensi yang dapat dimanfaatkan. Perilaku yang diharapkan untuk mendukung potensi ini adalah kreativitas dan hubungan komunikasi yang baik dengan berbagai pihak. Pihakpihak yang memiliki orientasi ini seperti sekolah formal maupun informal, dan media lokal. Terakhir ialah, 3) participatory orientation: menekankan pada penyebaran produksi dan komunikasi sebagai upaya untuk membangun pengetahuan, interaktivitas dan dialog. Memandang bahwa individu memiliki otonomi sehingga praktek informasi dan komunikasi terbuka dan bebas bagi siapapun.

Pilihan-pilihan orientasi tersebut secara nyata dapat merefleksikan cara pandang institusi memandang khalayak. Orientasi pertama yang dikenal di dunia ialah Protection. Pendekatan proteksi ini kepada masyarakat misalnya terjadi di Amerika pada era 50-an ketika awal film ditemukan. Proteksi ini dilakukan kepada anak-anak dengan memberitahu mereka bagaimana film bekerja (Hobbs dan Jensen, 2009: 2-3). Sedangkan di Eropa literasi media (filmproteksi) dilakukan pada periode 19601970an. Melalui eksplorasi film maka siswa dapat mengetahui relasi antara sistemsistem simbol, budaya, dan kognisi. Karena perbedaan mengenai bentuk simbol dan presentasi diproses oleh sistem mental, kemampuan dan kapasitas yang berbeda pula (Salomon, 1979: 379). Perbedaan waktu dan cara tersebut diakibatkan perbedaan konteks sosiologis, budaya dan teknologi yang berbeda-beda pada setiap wilayah negara. Artinya pendekatan pendidikan literasi akan selalu berkaitan dengan situasi dan kondisi dimana masyarakat hidup dan berkembang.

Sedangkan Promoting Orientation sama dengan pendekatan Creative Media Approach yang menitikberatkan pada pemberdayaan teknologi (technological empowerment) (Lee, 2010: 10). Pada posisi ini khalayak didorong untuk menggunakan teknologi sebagai bagian dari praktik untuk memproduksi keinginan mereka sesuai tujuan dan manfaat khalayak. Pemberdayaan ini melibatkan kemampuan khalayak tidak hanya mengakses namun membentuk pesan yang ingin disampaikan dengan cara-cara yang menarik, sehingga dapat melibatkan orang lain.

Orientasi yang terkahir muncul ialah participatory orientation, hal ini merujuk adanya Participatory Culture, individu harus memiliki keterikatan dengan budaya di dunia nyata, sehingga ia memahami apa yang dapat ia kontribusikan dalam dunia maya. Hal yang juga penting dipahami menjadi active contributor berarti mengaktifkan collective intelligence. Miminjam tulisan Henry Jenkins dan Danah ByoddalambukuThe Participatory Culture in a Networked Era, 2016, praktik komunikasi adalah praktik kebudayaan 
yang dibentuk dengan dukungan teknologi internet. Intelegensia kolektif didapatkan apabila individu memahami posisi dirinya sebagai masyarakat, kedewasaan bersikap, memahami konteks dan tentu saja ini terbentuk karena berbagai pengalaman di dunia nyata.

Lanjut Jenkins, budaya partisipasi melahirkan pertama, Affiliasi - keanggotaan kelompokyangaktifmembagidanmengkritisi informasi, di Indonesia kita dapat temukan dalam keanggotaan komunitas Kaskus atau Info Cegatan Jogja di sosial media Facebook. Kedua adalah Expression, pengguna media internet dapat membuat konten kreatif contohnya video tutorial make-up, cover lagu terbaru atau meme untuk mengkritik kinerja pemerintah misalnya. Ketiga, adalah Collaboration, tindakan ini bertujuan dalam mencari solusi bersama, misalkan melalui Wikipedia, setiap pengguna internet dapat saling menambahkan informasi tertentu sehingga dapat menghasilkan pengetahuan baru. Terakhir adalah, Cirlculations dimana sosial media ternyata memiliki dampak yang signifikan dalam kerja-kerja mainstream news media. Kerja-kerja jurnalistik misalkan bersumber pada "tweet" yang kontroversial sehingga dibahas dalam media massa dan selanjutnya dapat menjadi agenda publik.

Dalam periode literasi media di Eropa sejalan dengan ditemukan media komunikasi dan perkembangan teknologi yang menyertainya (Universidad Autonoma de Barcelona 2007: 30 dalam O'Neill, 2011:3) dapat diamati gerakan literasi media merupakan respon dari berkembanganya media massa dan media digital yang tumbuh pada perkembangan teknologi dan masyarakat dunia. Tahun 6o-an berkembangnya media film, hal ini membuat British Film Institute menjadikan film sebagai subyek pendidikan. Kemudian di tahun 70-an, perhatian berfokus pada televisi, masyarakat konsumen dan iklan sebagai bagian dari kritik gerakan literasi media. Era 8o-an, kekuatan komunikasi massa muncul berkaitan dengan berbagai cara alternatif mengakses dan bentuk partisipasi terhadap media. Pada posisi ini terjadi pengaturan kembali media massa televisi berikut masuknya ide mengenai digital literasi. Hal ini dikarenakan situasi masyarakat dan perkembangan media informasi di Eropa era 90-an dengan mulai masuknya fase konvergensi media.

\section{Literasi dan Warga Negara yang Aktif}

Tatanan dunia mulai berubah sejak dimulainya penemuan media massa. Karena berbagai penemuan televisi, komputer dan berbagai informasi yang dihasilkan di dalamnya. Kemudian Castell menyebutnya sebagai kapitalisme informasional. Konsekuensi hal ini adalah munculnya masyarakat-masyarakat informasional. Informasi menjadi modal perubahan sosial bisa bermakna positif, namun tidak lepas dengan berbagai tantangan. Tesis Castell itu kemudian dituliskan dalam buku triloginya berjudul Information Age: Economy, Society and Culture (1996, 1997, 1998). Refleksi Castell ini dimulai saat Amerika Serikat mulai menggunakan teknologi dan informasi sebagai cara pembentukan nalar dan perilaku warga negaranya sejak dekade 1970-an. Respon Castell ini juga muncul ketika masyarakat yang tidak dapat mengakses informasi kemudian seakanakan "tertinggal" oleh modernitas. Akses informasi menjadi kunci warganegara dapat menyuarakan sikap dalam masyarakat, mengakses hak-hak warga negara bahkan berkompetisi satu sama lain. Dunia menyodorkan kecenderungan baru muncul suatu masyarakat, kebudayaan, dan ekonomi baru bahkan bersifat dominatif. Pada konteks ini literasi media menjadi prioritas bagi Uni Eropa untuk menjadi bagian dari masyarakat informasional (O’Neill, 2008: 9).

Meskipun wujud eksploitasinya juga berbeda dengan bentuk kapitalisme sebelumnya namun peminggiran masih tetap terjadi. Sementara mereka akan terus ada, Castells (2007) melihat negara-negara menjadi simpul-simpul suatu jaringan kekuasaan yang lebih luas. Dilema yang dihadapi negara adalah bahwa ia mewakili konstituen nasionalnya, ia akan menjadi 
kurang efektif di dalam sistem global, tetapi jika ia berfokus pada sistem global, ia akan gagal mewakili secara memadai para konstituennya (Ritzer, 2012: 972). Kecakapan dan kompetensi menghadapi jaringan informasi dunia inilah yang menjadi tugas negara dalam menghadapi era masyarakat jaringan seperti hari ini.

Menurut Martinsson (2009: 3-4) masalah literasi menjadi penting bagi negara karena dalam proses literasi menyoal pada kemampuan "critical thingking, problem solving, personal autonomy, and social and communicative skills" yang menjadikan masyarakat aktif dalam mendukung dan mengkritisi pembangunan. Literasi media juga berkaitan bagaiman masyarakat pada akhirnya dapat bernegosiasi dengan warga negara yang lain, komunitas dan pemerintah dalam mengartikulasikan berbagai kepentingannya. Kemampuan warga negara mengartikulasikan pandangan politik ini mendukung adanya demokrasi yang sehat dan ruang publik yang setara. Oleh karena itu dalam peran-peran yang dijalankan pemerintah perlu mendukung dan melihat warga negara sebagai rekan kerja dalam berkolaborasi dalam menentukan arah kebijakan negara. Inilah yang menjadi semangat dalam demokrasi deliberative (kesepakatan bersama) menjadi bagian dari konsep warganegara yang aktif (Pérez Tornero \& Tapio Varis, 2010: 40-42).

Lebih lanjut merujuk pada UNESCO Policy Brief (2011) komponen-komponen penting dalam literasi digital baik pengguna komputer dan profesional ICT adalah: "mengakses, mengatur, mengevaluasi, mengintegrasikan, membuat, dan mengkomunikasikan informasi secara individu atau secara kolaboratif dalam jaringan, dengan bantuan komputer dan website berdasarkan lingkungan untuk pembelajaran, bekerja, dan waktu luang”. Artinya kegiatan literasi adalah proses yang berkesinambungan dan terus menerus. Warga negara aktif ialah, saat ia dapat menjadi bagian dari setiap proses literasi.

Masih menurut Martinsson (2009: 8), untuk mencapai partispasi aktif warganegara dan menciptakan ruang publik yang setara maka terdapat lima langkah program yang dapat dilakukan oleh pemerintah. Pertama, mendukung pengawasan terhadap media yang selanjutnya dapat berfungsi mengawasi kerja pemerintah ketika mengambil kebijakan, membuat anggaran hingga mengaplikasikannya. Kedua, mendukung lembaga ombudsmen untuk menjadi penghubung antara pemerintah dengan masyarakat. Sebagai lembaga netral ombudsmen dapat menjadi pihak yang mengelola aduan warga negara untuk disampikan pada pemerintah demi kesepakatan bersama. Ketiga, membangun kemampuan literasi media melalui forumforum interaksi yang membicarakan berbagai masalah media, komunitas atau negara secara kontekstual dan pengetahuan akademis. Keempat, mempromosikan literasi media sebagai elemen penting dalam menyusun program-program media. Dalam konteks ini warga negara diminta untuk dilibatkan dalam mengekpresikan kebutuhan mereka yang seharusnya di tayangkan di media. Kelima, mendukung kegiatan media literasi, aksi warga negara, dan pemerintahan yang baik melalui dukungan penelitian, workshop, diskusi terbuka dengan selalu bekerja sama terus menerus dengan berbagai pihak.

\section{METODE}

Perubahan metode dan pendekatan literasi media seperti penulis ungkapan sebelumnya selalu berkaitan dengan konteks politik, budaya dan teknologi masyarakat. Lalu bagaimana dengan pemerintah di Indonesia khususnya pemerintah Yogyakarta beserta komisi yang menjadi wakil di daerah merepon masyarakat informasi ini? Untuk menjawab pertanyaan tersebut penelitian ini menggunakan instrumen yang telah disusun melalui pengayaan teori digital literasi berkaitan dengan tujuan penelitian yaitu, memetakan aktivitas Literasi Digital. Menggunakan data yang berhasil dihimpun oleh Jaringan Pegiat Literasi Digital pada bulan Juli-September 2017, gerakan literasi digital di Yogyakarta 
dilakukan oleh perguruan tinggi dengan sebanyak 57 kali kegiatan, pemerintah 8 kali kegiatan, lembaga swadaya masyarakat 6 kali, komunitas dan sekolah masing-masing 1 kali kegiatan. Mayoritas gerakan literasi digital yang dilakukan perguruan tinggi berhubungan dengan kegiatan pengabdian masyarakat yang mendapatkan pendanaan dari kampus maupun negara melalui hibah penelitian dan pengabdian Direktorat Jenderal Pendidikan Republik Indonesia.

Menariknya pelaku gerakan literasi digital juga dilakukan oleh organisasi pemerintah yang terlihat beragam seperti kantor staf Kecamatan Kalasan, BKKBN, Kementerian Agama RI Provinsi DIY, KPID DIY, BNNP DIY dan RRI Pro 1 FM. Meskipun tidak selalu menjadi aktor utama, namun representasi pemerintah DIY dalam aktivitas literasi digital cukup terlihat. Karena tujuan penelitian ini untuk mengetahui aktivitas dan orientasi literasi media yang dilakukan oleh bidang institusi pemerintah daerah, maka peneliti memilih melakukan penelitian khusus kepada KPID DIY dan BTKP DIY.

Peneliti kemudian melakukan observasi langsung dan desk study melalui studi literatur, dan penelusuran berupa studi kasus melalui wawancara mendalam kepada kepala dan staff bimbingan teknologi di BTKP DIY dan komisioner KPID DIY pada rentang waktu Juli-September 2017. Observasi dilakukan untuk memahami konteks dan interaksi sosial yang ada di dalamnya. Melalui obeservasi ini peneliti akan dapat memahami situasi, aksi, norma dan nilai dari setiap kebijakan dan kegiatan yang dipilih oleh institusi negara. Dalam langkah selanjutnya peneliti akan dapat mendeskripsikan secara detail situasi dan kondisi yang mewakili realitas sesungguhnya di lapangan. Sedangkan desk study dipilih karena akan mencermati data-data sekunder berupa dokumen kegiatan yang dilakukan pemerintah. Peneliti mengkombinasikan dua metode ini untuk memahami paradigma pemerintah daerah Yogyakarta dan lembaga penyiaran DIY dalam melihat persoalan ini.

\section{HASIL DAN PEMBAHASAN}

Komisi Penyiaran Indonesia DIY merupakan bagian dari KPI Pusat. Melalui tugas, pokok dan fungsi lembaga negara ini memang tidak memiliki tanggung jawab langsung dalam mengkampanyekan gerakan literasi media. Namun, sesuai pengamatan dan wawancara yang peneliti lakukan kepada Komisioner ibu Sukiratnasari (14/o9/2017) ia menjelaskan bahwa setiap kegiatan evaluasi dengar pendapat media yang rutin diselenggarakan oleh KPID DIY, masyarakat banyak mengajukan pertanyaan mengenai tema-tema "media sehat", "parenting anak dan media", hingga soal "kecakapan digital". Dalam wawancara dan obesrvasi langsung peneliti menjumpai KPID DIY masih sering menggunakan logika masyarakat sebagai entitas pasif yang perlu dilindungi daripada diberdayakan.

Cara pandang yang banyak digunakan dalam melakukan aksi seminar, workshop dan diskusi masih berkutat pada posisi protecsionist model. Hal ini berorientasi bahwa orang tua adalah aktor paling penting dalam mengatur dan melindungi terpaan media kepada anak-anak mereka. Orang tua juga dianggap memiliki basis etika dan moral yang menjadi sumber anak-anakmemperoleh rujukan kebaikan dan keburukan dalam praktek hidup sehari-hari. Begitu pula peran negara, masih dilihat sebagai alat untuk mengontrol nilai, norma dan budaya yang disesuaikan dengan pandangan mayoritas masyarakat dengan berbasis pada agama tertentu.

KPID DIY sendiri secara rutin mengadakan Evaluasi Dengar Pendapat (EDP) dan sosialisasi penyiaran yang sehat untuk masyarakat, dengan demikian KPID DIY juga memposisikan dirinya sebagai pengontrol dan rujukan dalam memahami media. Dalam agenda kerja tahunan misalkan EDP dapat dilaksanakan lebih dari enam kali, dengan mengundang lembaga penyiaran swasta daerah untuk mendengarkan berbagai masukan dari masyarakat dan dari KPID sendiri. Tidak hanya itu melalui permintaan masyarakat desa dan institusi sekolah dapat mengajukan permohonan kerjasama untuk 
melakukan ceramah literasi media-digital kepada KPID DIY. Meksipun di luar Tupoksi (Tugas Pokok dan Fungsi) yaitu pengawasan konten siaran, namun KPID DIY mengaku bahwa tugas tersebut sebagai bagian dari cara mengajak masyarakat untuk dapat berpartisipasi dalam mengontrol konten media.

Meminjam Fedorov (2011: 74) protecsionist model adalah bagian dari mendidik dan memproteksi khalayak melalui nilai-nilai etika dan moral yang berlaku dalam sebuah masyarakat "educationalethical models the study of moral, religions, philosophical problems relying on the ethic, religious, ideological, ecological, protectionist theories of media education". Model ini mempercayai media adalah entitas yang memiliki pengaruh buruk, khalayak akan mudah mengikuti keburukan tersebut sehingga perlu untuk dilindungi. Etika dan moral penguasa menjadi acuan dalam mengendalikan masyarakat, tak dapat terelakkan bias dari kebaikan dan nilai tersebut bersifat subyektif sesuai kepentingan regulator.

Posisi ini sejalan dengan bagaimana pemerintah dalam negara berkembang sebagai pihak yang kuat dan memiliki pengaruh dalam kebijakan dan pola pikir masyarakatnya. Dalam realitasnya Komisi Penyiaran Pusat Republik Indonesia memang lebih sering melakukan sensor tubuh perempuan dengan menggunakan rujukan konsep "aurat” agama Islam. Konsep ini digunakan dengan melakukan blurring pada wilayah tertentu saat media menyiarkan sebuah program media. Bias norma dan nilai menjadi bagian kebijakan Negara dan menjadikan kebijakan proteksi tentu saja tidak sejalan dengan semangat kesetaraan yang justru menjadi roh warga negara yang aktif. Lebih lanjut menurut observasi yang dilakukan oleh peneliti

Penjelasan anggota komisioner Sukiratnasari (14/o9/2017) juga memberikan gambaran bagaimana KPID DIY hanya menjalankan tugas dan fungsi sesuai yang diamanatkan oleh undang-undang. Lebih spesifik Komisi Penyiaran ini berdiri sejak tahun 2002 berdasarkan Undang-undang Republik Indonesia Nomor 32 Tahun 2002 Tentang Penyiaran. KPI terdiri atas Lembaga Komisi Penyiaran Indonesia Pusat (KPI Pusat) dan Komisi Penyiaran Indonesia Daerah (KPID) yang bekerja di wilayah setingkat Provinsi. Wewenang dan lingkup tugas Komisi Penyiaran meliputi pengaturan penyiaran yang diselenggarakan oleh Lembaga Penyiaran Publik, Lembaga Penyiaran Swasta, dan Lembaga Penyiaran Komunitas. Menjadi penting untuk dipahami kemudian Undang-undang no. 32 Tahun 2002 tentang Penyiaran sesusngguhnya mengatur dua hal penting. Pertama, pengelolaan sistem penyiaran harus bebas dari berbagai kepentingan negara maupun swasta semata, hal ini dikarenakan penyiaran merupakan ranah publik. Kedua adalah semangat otonomi daerah dengan tujuan menguatkan entitas lokal melalui sistem sistem siaran berjaringan dari pusat ke wilayah daerah.

Lingkup undang-undang inilah ranah KPI Pusat dan KPID bekerja, merumuskan kegiatan setiap tahunnya dan menjalankan berbagai usahanya untuk memberikan hak publik dalam mendapatkan siaran bermedia yang mendukung demokrasi dan bermuatan pendidikan. Sehingga di luar tanggung jawab tugas dan fungsi tersebut, termasuk pendidikan literasi hanya sebagai bagian dari kerja-kerja yang diminta oleh publik, bukan menjadi tupoksi utama. Hal inilah yang membuat aktivitas gerakan literasi media yang dilakukan KPID DIY cenderung tidak fokus, kurang terukur, dan sporadis.

Lain halnya dengan BTKP Balai Teknologi Komunikasi Pendidikan Pemerintah Provinsinya DIY yang memang berfokus dalam pembelajaran pelajar dan guru dengan memberi nama forum ini sebagai Jogja Belajar (JB). Lembaga pemerintah ini memiliki jadwal tetap, yaitu kegiatan satu bulan bias melakukan tiga kegiatan pembelajaran, hingga setahun dapat tiga puluh angkatan membuka secara online pendaftaran berbagai pelatihan digital seperti bimbingan teknis (Bimtek) dan Kemah Ilmiah TIK, Bimtek Broadcasting (Presenter dan Penyiar), Produksi Pembelajaran Articulate Storyline, 
Bimtek pemanfaatan TIK Videoscribe, Bimtek produksi media pembelajaran VLOG, Workshop Inovatif Guru Kelas Virtual dengan Skype dan Share Point online, bahkan Jogja Belajar juga memiliki mobile learning service yang didatangkan ke sekolah-sekolah terpencil seperti di Kulon Progo dan Wonosari. Mobile learning ini berisi tidak hanya buku-buku sebagai media pembelajaran, namun seperangkat komputer yang dapat digunakan sebagai pengenalan siswa dan guru dalam metode pembelajaran.

Sepertiyang dijelaskanoleh Oki Pambudi salah satu staff BTKP yang diwawancarai penulis (12/o8/2017) berikut ini:

\section{"Saat ini BTKP mengembangkan layanan untuk menjangkau melalui mobile learning service kepada sekolah- sekolah yang terletak di daerah pedesaan yang belum ada jaringan internet atau sekolah-sekolah yang belum memiliki fasilitaslaboratorium komputer. Dengan adanya layanan tersebut diharapkan sekolah-sekolah daerah pedesaan akan mengenal TIK pendidikan dan terhindar dari buta internet/TI. Melalui mobile learning service yang dimulai sejak 2014, jangkauan pelayanan tersebar 100 sekolah di kabupaten/kota se-DIY”.}

Aktivitas BTKP DIY ini dibawah Dinas Pendidikan Pemuda Olahraga DIY. Sampai dengan tahun 2017 ini BTKP DIY telah mengembangkan, mengkaji, dan melayani berbagai kegiatan yang berkaitan dengan perkembangan teknologi informasi di bidang pendidikan. Adapun sasarannya adalah semua siswa dan pendidik baik formal, non formal, PLB, madrasah, dan masyarakat DIY. Sesuai observasi dan wawancara peneliti akativitas ini tidak hanya menggunakan media komputer dan jaringan internet dengan media website, namun konvergensi media juga dilakukan. Terdapat beberapa program kegiatan unggulan berbasis internet yang saat ini dikembangkan antara lain seperti: video streaming (jogya belajar tube), radio streaming (jogya belajar radio), pembelajaran secara on line kelas maya (jogya belajar virtual classroom), layanan konten media budaya Yogyakarta (jogya belajar budaya), layanan konten pembelajaran berbasis multi media interaktif (jogya belajar media), produksi media video pembelajaran berupa film video maupun animasi. Produksi pembuatan karya tulis ilmiah di bidang pendidikan berbasis TIK juga menjadi bagian dari variasi bimbingan teknis yang ditawarkan pada guru-guru yang mengampu mata pelajaran tertentu, hasil karya ilmiah ini kemudian dipublikasikan dalam jurnal ilmiah "Adi Karsa" dan bulletin "Warta".

Sesuai wawancara peneliti dengan Bening staff kordinator Jogja Belajar radio (27/07/2017) Untuk program radio streaming sudah dimulai sejak tahun 2014, dengan memberi layanan kepada stakeholder pendidikan secara on line di portal web site BTKP DIY selama 24 jam terus-menerus melalui jogya belajar radio, sehingga siswa, guru, dan masyarakat dapat berinteraksi secara intensif kaitannya dengan informasi pendidikan yang sedang ditayangkan. Narasumber yang dihadirkan juga beragam seperti guru dan mentor yang di ambil dari perwakilan MGMP (Musyawarah Guru Mata Pelajaran) yang mampu dan tertarik dalam kegiatan penyiaran radio. Mereka diundang dengan kompetensinya masing-masing untuk mengulas pertanyaan dalam mata pelajar tertentu, berikut cara-cara menjawab soal-soal yang tidak mudah dipecahkan siswa belajar.

Dalam observasi dan wawancara peneliti melihat Provinsi DIY melalui BTKP sudah berusaha melakukan kegiatan yang sistematis berkaitan kegiatan, dengan latar belakang sesuai Tupoksinya BTKP DIY adalah mendukung tercapainya visi dan misi Dinas Dikpora DIY melalui pengembangan, produksi, dan layanan media pembelajaran berbasis teknologi informasi komunikasi (TIK) kepada pendidikan formal, non formal padajenjangpendidikandasardanmenengah. Kondisi ini sejalan dengan ruang lingkup BTKP DIY sebagai UPT (Unit Pelaksana Teknis) Daerah di bawah Dinas Dikpora DIY berdasarkan Peraturan Pemerintah Nomor 41 Tahun 2008 tentang SOTK dan Tupoksi terdiri dari: Kepala Balai; Subbag Tata Usaha; Seksi Layanan dan Promosi; Seksi 
Pengembangan dan Produksi; dan Kelompok Jabatan Fungsional (Ngatifudin Firdaus, staff bimtek 27/07/2017).

BTKP DIY memliki sejarah bahwa awalnya adalah sanggar belajar milik Pustekom yang kemudian diserahkan ke Pemda menjadi UPTD dalam struktur dan fungsi jabatan berada di eselon III. Setelah terjadi pembenahan dan berada langsung di bawah Dinas Pendidikan dan Olahraga DIY maka terjadi perombakan dan perubahan visi misi. Apalagi sejak 2010 DIY menjadi Sister City Kyoto mendapatkan ICT-EQAP bantuan perangkat Komputer dari Jepang sebanyak 500 buah. Berikut pendanaan Anggaran 200 Milyar 2010-2014 dibagi kedalam tiga tahun penganggaran bertahap. Tahun pertama 75 sekolah, tahun kedua 200 sekolah dan tahun ketiga 225 sekolah. Anggaran yang disalurkan rata-rata 70 Milyar pertahun. Sumber pendanaan ini adalah bentuk pinjaman dari JICA (Japan International Cooperation Agency). Tidak hanya itu bentuk lain dari program Sister City Kyoto adalah memberangkatkan hampir sepuluh guru pertahun selama sebulan. Pada tahun 2017 ini Keminfo ingin menduplikasi program serupa ke kota lain. Karena kesuksesan ini pula Pemprov DIY dianugerahi tiga tahun berturut-turut sejak 2014-2016 Ki Hajar Award sebagai Provinsi yang menyediakan layanan pendidikan terbaik di Indonesia. Penghargaan ini juga dinilai berdasarkan jumlah anggaran yang dikelola, kesiapan pemerintah dalam menyalurkan dana dan keterbukaan informasi ini kepada publik.

Kemampuan digital literacy termasuk diantaranya ketika pengguna memliki kemampuan berpartisipasiaktif. OlehUnesco kecakapan literasi digital termasuk bagian dari cara mengukur masyarakat apakah telah siap masuk dalam masyarakat informasi, sehingga mendefinisikan kecakapan literasi adalah kemampuan untuk hidup "digital literacy as a life skill" (UNESCO-Policy Brief, 2011). Definisi ini menjelaskan bagaiman kehidupan dunia telah berubah, siapa yang menguasai dan dapat mengakses informasi digital adalah manusia-manusia yang "memenangkan" dunia. Hal ini dikarenakan dalam pekerjaan-pekerjaan di masa depan kerja kolaboratif lebih diutamakan daripada kerja-kerja kompetitif.

Kerja kolaboratif ini berarti setiap orang memiliki peranan yang saling melengkapi. Sehingga dunia digital di masa depan juga memunculkan kerja egaliter atau setara satu sama lain daripada berjenjang saat masa pekerjaan dilakukan secara manual. Tidak hanya kerja-kerja kolaboratif namun kreativitas menjadi keutamaan dalam penggunana ICT (Integrated Communication Technology). Karena posisi khalayak, sekarang disebut pengguna media (user) tidak lagi hanya mengkonsumsi (consuming) seperti akhir abad 20, namun beralih pada produksi pesan-produk (producing) pada abad 21 ini. "Collabora tive knowledge construction and creativity" adalah kunci menghadapi kehidupan yang serba digital. Sepanjang obeservasi yang dilakukan oleh peneliti, BTKP DIY telah dapat melakukan kerja-kerja nyata yang dapat mendukung kerja-kerja kolaboratif. Guru dan siswa diajarkan untuk dapat menggunakan perangkat digital yang sistematis dan terukur. Meskipun tidak dapat dipungkiri keterbatasan ruangan, waktu dan anggaran masih menjadi persoalan sehingga tidak semua guru dan siswa dapat diberikan kesempatan yang sama, melainkan kompetisi dalam pendaftaran pelatihan.

\section{SIMPULAN}

Merujuk pada sepuluh kompetensi Literasi Digital yang telah di sarikan oleh Japelidi (Jaringan Pegiat Literasi Digital), tiga hal yang paling krusial dalam kemampuan literasi adalah menganalisis, memverifikasi dan mengevaluasi. Kemampuan ketiga hal tersebut tidak pula datang dengan tiba-tiba. Terlebih dahulu individu perlu bersinggungan dengan kemampuan literasi media konvensional yaitu membaca, kebiasaan bersinggungan dengan teks media yang lain yang tidak semata berbasis pada budaya visual, dan yang terpenting individu perlu untuk memiliki pengalaman riil di luar zona nyaman mereka. Artinya adalah, literasi merupakan bagian dari kebudayaan, interaksi sehari-hari, tindakan 
yang dibiasakan, dilakukan terus menerus dan menjadi sebuah kebutuhan.

Khalayak aktif menjadikan titik tolak pemberdayaan masyarakat. Karena dalam masyarakat yang melek terhadap media digital maka warga negara yang aktif dalam partisipasi demokrasi dapat tercipta (Mihailidis dan Thevenin, 2013: 1614). Dalam dunia digital partisipasi demokrasi masyarakat sipil dapat terjadi tidak hanya dalam pergerakan dan perlawanan politik yang besar namun juga dipahami dalam persoalan politik sehari-hari yang berkenaan isu-isu publik. Penggunaan sosial media yang semakin konvergen sebagai contoh melahirkan berbagai respon politik dengan menggunakan gambar digital yang di edit seperti meme sebagai upaya kritik sosial. Pada realitas ini peran negara harus sudah mulai beralih dari posisi proteksi menjadi aktif sebagai jembatan pendidikan dengan penyiadaan fasilitas digital bagi publik.

Sebagaimana paparan peneliti di atas KPID DIY terlihat masih menampilkan dirinya sebagai pihak yang "memadamkan api" di masyarakat, namun belum pada pencegahan bagaimana api itu bisa menyala menjadi kebakaran. Hal ini sejalan dengan TUPOKSI yang melekat pada lembaga negara ini. Fungi-fungsi negara yang belum memberdayakan masih nampak dalam kegiatan-kegiatan sosialisasi dan kampanye literasimediayang merekaselenggarakan. Hal ini berbeda dengan fungsi BTKP DIY. Namun BTKP DIY dalam kegiatannya masih belum mencoba melakukan elaborasi bimbingan teknologi bersama-sama antara murid dan guru. Memiliki proyek bersama-sama dalam kerangka kerja setara. Nampaknya ini yang masih harus diupayakan terus menerus.

Meski demikian usaha untuk memberikan wawasan dan pendampingan teknologi sudah menuju arah kebaikan mewujudkan lingkungan pendidikan yang melek digital sudah terlihat. Usaha-usaha untuk "menjemput bola" dan pemerataan akses pelatihan dan pendidikan dilakukan melalui mobile e-learning menjadi langkah yang baik sebagai institusi pendukung pendidikan di daerah. Pelatihan yang dilakukan melalui pelayanan pembelajaran berbasis web oleh BTKP DIY seperti: e-learning, e-office dan e-government di jaringan internet juga sudah mengarah pada orientasi partisipasi aktif.

Sejalan dengan orientasi partisipasi yang menekankan tindakan participatory culture yang juga dapat disebut bagian dari The New of Media Literacies. Kita dapat melihat bagaimana tidak hanya melek media namun partisipasi adalah tindakan kebudayaan. Seharusnya individu didorong tidak berhenti dalam partisipasi di dunia digital, namun ia harus mengaplikasikannya dalam dunia nyata. Hal inilah yang menjadi penekanan dari collective intelligence.

\section{DAFTAR PUSTAKA}

Ashley. Seth; Maksl, Adam; and Craft, Stephanie. (2017). "News Media Literacy and Political Engagement: What's the Connection?", Journal of Media Literacy Education, Volume 9, No. 1, hal.79 -98.

Castells. M. (2009). The Power of Identity: The Information Age: Economy Society, and Culture Volume II, $2^{\text {nd }}$ Edition with a New Preface. Wiley-Blackwell.

Castells. M. (2012). Networks of outrage and hope: Social movements in the Internet age. Cambridge, UK: Polity.

Donald J. Leu, Jr., Charles K. Kinzer, Julie L. Coiro, and Dana W. Cammack. (2004). Toward a Theory of New Literacies Emerging From the Internet and Other Information and Communication Technologies From Theoretical Models and Processes of Reading. (5th ed.). International Reading Association.

Fedorov. A. (2011). Modern media education models. Acta Didactica Napocensia, Volume 4, No. 1, hal.73-82.

Hobbs, R., \& Jensen, A. (2009). The Past, Present, and Future of Media Literacy Education. Journal of Media Literacy Education, Volume 1, hal. 1-11.

Jenkins. H. (2006). Convergence culture: Where old and new media collide. New 
York, NY: New York University Press.

Jensen. A.P. (2008). Beyond Mediatized Transmissions of Youth Culture: A Study in Digital Citizenship. Youth Theatre Journal, Volume 23, No. 1, hal.14-28.

Lee. A.Y. L. (2010). Media Education: Definitions, Approaches and Development around the Globe. New Horizons in Education, Volume 58, No. 3, hal. 1-13.

Leu, Don \& K Kinzer, Charles \& Coiro, Julie \& W Cammack, Dana. (2004). Toward a Theory of New Literacies Emerging From the Internet and Other Information and Communication Technologies. Theoretical Models and Processes of Reading. 5th ed. International Reading Association.

Livingstone. S. dan Bovill, M. (1999). Young People New Media. Report of the Research Project Children Young People and the changing Media Environment. London: LSE.

Martinsson.Johanna.(2009).Communication for Governance and Accountability Program (CommGAP) COMMGAP DISCUSSION PAPERS Innovative Solutions FOR GOVERNANCE The Role of Media Literacy in the Governance Reform Agenda. Washington DC: Communication for Governance \& Accountability Program (CommGAP).

McLuhan. Marshall. (1964). Understanding Media. New York: McGraw-Hill.

Mihailidis. Paul dan Benjamin Thevenin. (2013). Media Literacy as a core Competency for Engaged Citizenship in Participatory Democracy. American Behavioral Scientist.Volume 57, No. 11, hal. 1611-1622.

Neuman. W.L. (2006). Social Research Methods: Qualitative and Quantitative Approaches. $7^{\text {th }}$ ed. Harlow: Pearson Education.

Nugroho, Garin dan Dyna Herlina. (2013). Krisis dan Paradoks Film. Jakarta:
Gramedia Pustaka Utama.

O'Neill. B. (200o). 'Media Education in Ireland'. Irish Communications Review. Volume 8, hal. 57-64.

O’Neill. B. (2011). Media Literacy in Ireland: From Protectionism to Participation. Presentation at Media Literacy - A Critical Moment Conference. Dublin.

O’Neill. B., dan Barnes, C. (2007). Media Literacy and The Public Sphere: a Contextual Study for Public Media Literacy Promotion in Ireland. Dublin: Centre for Social and Educational Research, Dublin Institute Technology.

R. Hobbs. dan A. Jensen. (2009). The Past, Present, and Future of Media Literacy Education. The National Association for Media Literacy Education's Journal of Media Literacy Education 1.

R. Hobbs. (2010). Digital and Media Literacy: A Plan of Action a White Paper on the Digital and Media Literacy Recommendations of the Knight Commission on the Information Needs of Communities in a Democracy. Washington: The Aspen Institute.

Rainie. L., Brenner, J., and Purcell, K. (2012). Photos and videos as social currency online. Pew Internet \& American Life Project.

Ritzer. George. Douglas J. Goodman. (2012). Teori Sosiologi dari Teori Sosiologi Klasik Sampai Perkembangan Mutakhir Teori Sosial Postmodern. Bantul: Kreasi Wacana.

Rogers. Everett M. (1983). Diffusion of Innovations, Third Edition. New York, NY: The Free Press.

Salomon. G. (1979). Interaction of media, cognition and learning. San Francisco, CA: Jossey Bass.

Sen. Khrisna, dan David T Hill. (2000). Media, Culture and Politics in Indonesia. Oxford University Press.

Tornero. Pérez J.M., Varis, Tapio. (2010). Media Literacy and New Humanism. Moscow: 
INFORMASI Kajian Ilmu Komunikasi Volume 48. Nomor 2. Desember 2018

UNESCO Institute for Information

Technologies in Education.

Policy Brief, UNESCO, 2011. 